\title{
Recovery of Big Sagebrush Following Fire in Southwest Montana
}

\author{
Peter Lesica, ${ }^{1}$ Stephen V. Cooper, ${ }^{2}$ and Greg Kudray ${ }^{3}$ \\ Authors are ${ }^{1}$ Senior Scientist, Conservation Biology Research, 929 Locust, Missoula, MT 59802; ${ }^{2}$ Ecologist and \\ ${ }^{3}$ Ecology Program Manager, Montana Natural Heritage Program, 1515 East Sixth Avenue, Helena, MT 59620.
}

\begin{abstract}
Fire plays a large role in structuring sagebrush ecosystems; however, we have little knowledge of how vegetation changes with time as succession proceeds from immediate postfire to mature stands. We sampled at 38 sites in southwest Montana dominated by 3 subspecies of big sagebrush (Artemisia tridentata Nutt.). At each site we subjectively located 1 sample plot representing the burned area and an unburned macroplot in similar, adjacent, unburned vegetation. Canopy cover of sagebrush was estimated, and plants were counted in 10 microplots. Age and height of randomly chosen sagebrush plants in each size class were determined from 5 microplots. Average postfire time to full recovery of mountain big sagebrush (ssp. vasseyana [Rydb.] Beetle) canopy cover was 32 years, shorter for basin (ssp. tridentata) and much longer for Wyoming (ssp. wyomingensis Beetle \& Young) big sagebrush. Height recovered at similar rates. There was no difference in canopy cover or height recovery between prescribed fires and wildfires in stands of mountain big sagebrush. We found no relationship between mountain big sagebrush canopy cover recovery and annual precipitation, heat load, or soil texture. Nearly all unburned sagebrush macroplots were uneven-aged, indicating that recruitment was not limited to immediate postfire conditions in any of the subspecies. Average canopy cover of three-tip sagebrush (A. tripartita Rydb.) did not increase following fire, and many three-tip sagebrush plants established from seed instead of sprouting. Our results suggest that the majority of presettlement mountain big sagebrush stands would have been in early to midseral condition in southwest Montana assuming a mean fire interval of 25 years. Only long firereturn intervals will allow stands dominated by Wyoming big sagebrush to remain on the landscape in our study area. We speculate that effects of site-specific factors conducive to sagebrush recovery are small compared to stochastic effects such as fire.
\end{abstract}

\section{Resumen}

El fuego jugó un gran papel en estructurar los ecosistemas de "Sagebrush"; pero, tenemos poco conocimiento de cómo la vegetación cambia con el tiempo conforme la sucesión se desarrolla, desde el momento inmediato después del fuego hasta las poblaciones maduras. Muestreamos 38 sitios en el suroeste de Montana dominados por tres subespecies de "Big sagebrush" (Artemisia tridentata Nutt.). En cada sitio, localizamos subjetivamente una parcela representando el área quemada y una macroparcela adyacente de vegetación similar sin quemar. La cobertura de copa del "Sagebrush" fue estimada y las plantas se contaron en 10 microparcelas. En cinco microparcelas, se determinó la edad y altura de plantas de "Sagebrush" elegidas aleatoriamente dentro de cada categoría de tamaño. El tiempo promedio para la recuperación total de la copa del "Mountain big sagebrush" (ssp. vasseyana [Rydb.] Beetle) después del fuego fue de 32 años, periodo más corto que para el "Basin" (ssp. tridentata) y mucho más largo que el del "Wyoming (ssp. wyomingensis Beetle \& Young) big sagebrush." La altura se recuperó a tasas similares, y no hubo diferencia en la recuperación de la cobertura de copa y altura de poblaciones de "Mountain big sagebrush" sujetas a fuegos prescritos o fuegos naturales. No encontramos relación entre la recuperación de la cobertura de copa del "Mountain big sagebrush" y la precipitación anual, carga de calor, o textura del suelo. Casi todas la macroparcelas de "Sagebrush" sin quemar fueron uniformes en edad, indicando que el establecimiento de plántulas de todas las subespecies no estuvo limitado por las condiciones inmediatas posteriores al fuego. La cobertura de copa promedio del "Three-tip sagebrush" (A. tripartita Rydb.) no se incrementó después del fuego, y muchas de las plantas de esta subespecie se establecieron a partir de semilla en lugar de rebrotes. Nuestros resultados sugieren que la mayoría de las poblaciones "Big sagebrush" del suroeste de Montana, presentes antes de la colonización, pudieran haber estado en una condición de etapa seral inicial a intermedia, asumiendo una media del intervalo entre fuegos de 25 años. Solo intervalos largos entre fuegos permitiría a las poblaciones dominadas por "Wyoming big sagebrush" permanecer en el paisaje de nuestra área de estudio. Especulamos que los efectos de los factores específicos del sitio que conducen a la recuperación de "sagebrush" son pequeños en comparación con los efectos estocásticos, tales como el fuego.

Key Words: Artemisia tridentata, Artemisia tripartita, fire effects, sagebrush, succession

\section{INTRODUCTION}

This research was funded by The Montana Office of the USDI Bureau of Land Management. Correspondence: Peter Lesica, Conservation Biology Research, 929 Locust, Missoula, MT 59802. Email: peter.lesica@mso.umt.edu

Manuscript received 26 February 2006; manuscript accepted 20 February 2007.
Sagebrush steppe is an important vegetation type in intermountain western North America. Woody species of sagebrush (Artemisia spp.) especially big sagebrush (A. tridentata Nutt.) dominate these semiarid landscapes and provide habitat for numerous species of plants and animals. 
Fire played a large role in structuring presettlement sagebrush ecosystems, creating a mosaic of stands of different size in various seral conditions (West 2000). It is reasonable to assume that conserving native species diversity will require a similar mosaic. For example, sage grouse (Centrocercus urophasianus) require barren areas for leks, relatively dense stands of medium height for nesting (Klebenow 1969; Wallestad and Pyrah 1974; Aldridge and Brigham 2002), open stands for brood rearing (Wallestad 1971; Klebenow 1973), and tall stands with a full canopy for wintering (Eng and Schladweiler 1972). Presumably sage grouse populations can be limited by the loss of any 1 of these habitat types (Connelly et al. 2000; Roscoe 2002).

Agriculture, livestock grazing, herbicide treatments, prescribed fire, and fire suppression have changed the amount, distribution, and characteristics of big sagebrush stands in southwest Montana (Lesica and Cooper 1997; Harrington 2002). Three ecotypes of big sagebrush occur in southwest Montana. Basin big sagebrush (Artemisia tridentata Nutt. ssp. tridentata) is a large, fast-growing form occurring in sandy soils, particularly on stream terraces at lower elevations. Mountain big sagebrush (A. tridentata ssp. vaseyana [Nutt.] Beetle) is a medium-sized shrub that occurs at higher elevations with greater annual precipitation, especially snow. Wyoming big sagebrush (A. tridentata ssp. wyomingensis Beetle \& Young) is found in the most arid habitats, upland sites at low elevations. Extensive stands of basin big sagebrush have been converted to hay meadows. Fire suppression and livestock grazing have lowered fire frequency (Arno and Gruell 1983), likely increasing the proportion of dense-canopy mountain big sagebrush stands, whereas extensive herbicide application during the second half of the last century had the opposite effect.

Management strategies that promote the conservation of all species dependent on sagebrush steppe vegetation are just now being developed. Prescribed fire has been proposed as means to control the density of big sagebrush stands (Klebenow 1973; Pyle and Crawford 1996); however, we have little knowledge of how sagebrush canopy cover and height changes with time as succession proceeds from immediate posttreatment to mature and old-growth stands. Big sagebrush is considered a climax-dominant species, although it might require many years to re-establish on sites following fire (Harniss and Murray 1973; Wambolt and Payne 1986; Wambolt et al. 2001), perhaps depending on soil texture (Gruell 1980). Lateseral big sagebrush stands often have a dense canopy and are considered by many to be self-perpetuating in the absence of fire (Westoby et al. 1989; Laycock 1991). However, big sagebrush dominance might decline with age when adequate precipitation favors residual bunchgrasses (Anderson and Inouye 2001). The age structure of sagebrush populations is likely to have a strong influence on the dynamics of these communities. Comprehensive management of sagebrush at the landscape scale cannot be accomplished without understanding how structural and compositional attributes change with time since disturbance.

The purpose of this study was to document how sagebrush canopies change with time since fire in southern Beaverhead and adjacent Madison counties, Montana. We inferred changes in sagebrush height, cover, and age-class distribution by sampling numerous stands of various ages in common

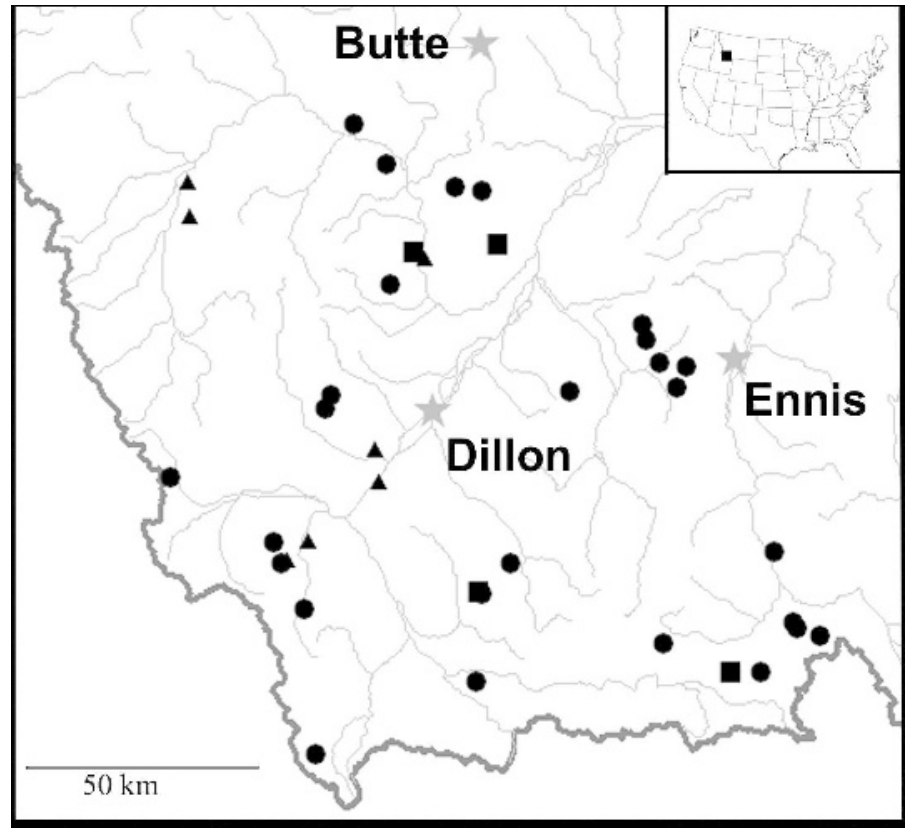

Figure 1. Location of study sites in southwest Montana for ssp.

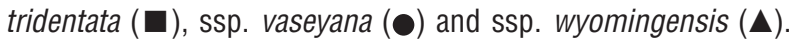

sagebrush habitat types. We asked whether recovery of sagebrush height and canopy cover varied among subspecies and between prescribed fire and wildfire. Our study design allowed us to assess whether climate, soil texture, or other site characteristics were strongly associated with rate of recolonization by big sagebrush and how recruitment varied with time since fire. Our results can be integrated with existing knowledge of sagebrush-dependent species habitat requirements to develop management plans that use prescribed fire to create a mosaic that will meet management needs for wildlife conservation.

\section{METHODS}

\section{Study Area}

Study sites were located in Beaverhead, Madison and adjacent Silver Bow counties in southwest Montana (Fig. 1), all of which is part of the Beaverhead Mountains Section of the Middle Rocky Mountains Steppe-Coniferous Forest-Alpine Meadow Province (Bailey 1995; Nesser et al. 1997). Elevations ranged from 1615 to $3230 \mathrm{~m}$ with the mountains being almost exclusively block faulted and formed of igneous, sedimentary, and metasedimentary rocks. Despite the predominance of high elevations, forest vegetation is considerably less extensive than Artemisia-dominated shrub-steppe. Dillon (1590 m) and Lakeview $(2045 \mathrm{~m})$ are the lowest and highest climate recording stations in our study area (NOAA 1982). Mean daily January and July temperatures at Dillon were $-6.6^{\circ} \mathrm{C}$ and $19.0^{\circ} \mathrm{C}$, respectively, and mean annual precipitation was $242 \mathrm{~mm}$. At Lakeview, mean daily January and July temperatures were $-11.3^{\circ} \mathrm{C}$ and $14.9^{\circ} \mathrm{C}$, respectively, with mean annual precipitation of $521 \mathrm{~mm}$. Approximately $50 \%-65 \%$ of precipitation falls during the short growing season of May through September. 


\section{Field Methods}

We sampled at 38 sites dominated by 1 of three subspecies of big sagebrush: mountain (ssp. vaseyana, $n=28$ ), basin (ssp. tridentata, $n=4$ ), or Wyoming (ssp. wyomingensis, $n=6$ ) in Beaverhead and Madison counties below $2450 \mathrm{~m}$ in elevation (Fig. 1) in June and July of 2003 and 2004. Three-tip sagebrush (A. tripartita) occurred in 9 of these stands. Sites were stratified by county, ignition source (prescribed vs wild), subspecies of sagebrush, and time since fire. They were randomly selected from a pool of more than 100 prescribed burns and wildfires provided by the Dillon Office of the Bureau of Land Management, Beaverhead-Deerlodge National Forest, and Montana Department of Fish, Wildlife and Parks. We used the dates of ignition provided by the land management agencies to determine the time since fire for each site. Prescribed fires occurred during early spring and autumn, whereas most wildfires occurred during late summer. We avoided sites with a history of herbicide application.

Sample macroplots were $20 \times 50 \mathrm{~m}$. At each site we subjectively located 1 sample plot that appeared to represent the majority of the burned area. We located an unburned sample macroplot as close to the burn as possible in adjacent vegetation with similar aspect, slope, and soil as the burned plot. Unburned macroplots plots were not true controls because they were not randomly assigned prior to the fires; however, they act as controls by representing what burned plots would be like had they not burned. Burned macroplots were always located within $300 \mathrm{~m}$ or less from the sagebrush seed source of the unburned macroplot and always in the same grazing pasture. We have no way of accurately assessing immediate postfire grazing regimes; however, we did take care to locate sample plots well away from water developments and fence lines to help insure that grazing pressure was not above average for the pasture.

Canopy cover of sagebrush was estimated using the lineintercept method along 5 evenly-spaced, parallel, 20-m transects originating from the 50-m macroplot baseline (Mueller-Dombois and Ellenberg 1974). Sagebrush plants were classified into 4 size classes: seedlings $(<10 \mathrm{~cm}$ high), juvenile ( $>10 \mathrm{~cm}$ high and $<1 \mathrm{~cm}$ diameter), small mature $(1-3 \mathrm{~cm}$ diameter), large mature ( $>3 \mathrm{~cm}$ diameter), and counted in 10, $3-\mathrm{m}^{2}$ circular microplots located at the 5-meter and 15 -meter marks along the 5 transect lines.

Age and height of 1 randomly chosen sagebrush plant in each size class were determined from alternate microplots (a total of $5)$. Sagebrush plants were severed at ground level, and we counted annual growth rings in the field with a $10 \times$ hand lens (Ferguson 1964). It was more difficult to accurately measure the age of plants greater than 30 years old, especially plants of three-tip sagebrush. We excavated three-tip sagebrush plants to a depth of $10 \mathrm{~cm}$ to be certain that we were making cross sections at the true root crown. However, we might not have always been able to recognize plants that sprouted from small lateral roots. We noted age measurements for which we were not confident, and these were not used in analyses. When 1 or more size classes were not represented in all 5 sample plots, we sampled plants outside the microplots to insure that we had at least 3 estimates for each size class in each macroplot. We failed to measure sagebrush heights at 7 of the sites.
In each macroplot, $3125 \mathrm{~cm}^{3}$ soil samples, spatially separated approximately $5 \mathrm{~m}$, were collected from the $5-15 \mathrm{~cm}$ depth interval. Macroplot soil samples were combined and analyzed for particle-size distribution by a modified Bouyoucos hydrometer method (Day 1965).

In September 2004 we located a macroplot in a stand of mountain big sagebrush and three-tip sagebrush on the south side of the Centennial Valley in the southern part of our study area. This stand had been burned by the hot Winslow wild fire in August of the previous year. We recorded the number of dead and resprouting three-tip sagebrush plants in 10 randomlylocated $3-\mathrm{m}^{2}$ circular microplots as described above.

\section{Data Analysis}

We defined sagebrush recovery as the mean big sagebrush canopy cover or height for the burned macroplot divided by those values for the unburned macroplot: we measured the recovery of the burn plot at each site in relation to what it would have been had it not burned. Height of the dominant cohort (size class with the most canopy cover) was used to evaluate changes in stand height. Rate of sagebrush recovery for canopy cover and height is recovery divided by the number of years since fire. For unburned macroplots we estimated time since fire as the age of the oldest measured plant. We examined differences in number of big sagebrush cohorts, defining a sagebrush cohort as all plants within a 5-year age span separated from other cohorts by 2 or more years.

We hypothesized that recruitment and other aspects of sagebrush recovery would depend on the relative aridity of a site, which depends on precipitation as well as potential evapotranspiration. The latter is determined primarily by slope and aspect. These 2 variables have been integrated into an index of heat loading by McCune and Keon (2002). Mean annual precipitation for each site was estimated using DAYMET, a model that integrated elevation and other aspects of local terrain with weather station data for the past 18 years (Thornton et al. 1997). We regressed the number of sagebrush plants recruited on seasonal precipitation $($ winter $=$ January + February + March, spring $=$ April + May + June, etc.) recorded at Dillon for each of the past 35 years to examine the effect of interannual climate changes over our study area.

We used paired-sample $t$-tests to assess the differences between burned and unburned macroplots in three-tip sagebrush canopy cover and height. We used linear regression analysis to model the recovery of sagebrush height and canopy cover with time since fire. Models were constrained to have the regression line pass through the origin. Regression analysis was also used to test the association between sagebrush canopy cover and height recovery rate and the abiotic site factors: precipitation, soil texture (\% sand), and heat load index. We used one-way or two-way analysis of variance (hereafter referred to as ANOVA) followed by contrast tests to assess the differences between subspecies of big sagebrush and season of fire in canopy cover and height recovery with time since fire as a covariate in the models. Recovery and recovery rates were log-transformed for these analyses (see Results). We also tested the effect of prescribed fire versus wildfire on big sagebrush age-class distribution with ANOVA. Recovery with time since fire was a covariate in these models to account for successional 
changes unrelated to the dependent variables. We tested for differences in annual precipitation, soil, and heat load among subspecies with ANOVA followed by contrast tests. We present means followed by \pm 1 standard error.

\section{RESULTS}

\section{Big Sagebrush Recovery}

We sampled all of the burned sites dominated by Wyoming big sagebrush known to us in our study area. Time since fire ranged from 8 to 23 years with a median of 15 years in the burned macroplots. Mean canopy cover of Wyoming big sagebrush in unburned macroplots was $15 \pm 2 \%$. Mean height of the dominant Wyoming big sagebrush cohort in unburned macroplots was $61 \pm 7 \mathrm{~cm}$. Time since fire in burned macroplots of mountain big sagebrush ranged from 3 to 34 years with a median of 16 years. Mean canopy cover of mountain big sagebrush in unburned macroplots was $28 \pm 2 \%$. Mean height of the dominant mountain big sagebrush cohort in unburned macroplots was $76 \pm 4 \mathrm{~cm}$. We sampled all 4 burned sites dominated by basin big sagebrush located in our study area. Time since fire ranged from 11 to 30 years with a median of 24 years. Mean canopy cover of basin big sagebrush in unburned macroplots was $20 \pm 2 \%$. Mean height of the dominant basin big sagebrush cohort in unburned macroplots was $131 \pm 6 \mathrm{~cm}$. Fire resulted in an almost complete loss of canopy across all subspecies. Mean canopy cover for recently burned macroplots $(<10$ years, $N=10)$ for all subspecies combined was $3 \%$ with a median of less than $1 \%$, whereas both mean and median were $26 \%$ for unburned plots.

The 3 subspecies of big sagebrush occupy different abiotic environments. Mean annual precipitation for mountain big sagebrush sites was $530 \pm 17 \mathrm{~mm}$, greater than for either Wyoming $(380 \pm 11 \mathrm{~mm})$ or basin $(415 \pm 78 \mathrm{~mm})$ big sagebrush sites $\left(\mathrm{F}_{1,35}>5.3, P<0.027\right)$. Mean annual precipitation between the latter 2 subspecies did not differ $\left(F_{1,35}=0.3, P=0.57\right)$. Percent sand was a good index of overall soil texture because it was strongly associated with both $\%$ clay $(r=-0.72)$ and silt $(r=-0.92)$. Mean percent sand was $70 \pm 7 \%$ for basin big sagebrush sites, greater than either Wyoming $(40 \pm 3 \%)$ or mountain $(47 \pm 3 \%)$ big sagebrush sites $\left(\mathrm{F}_{1,35}>11.8, P<0.002\right)$. Soils did not differ between Wyoming and mountain big sagebrush sites $\left(\mathrm{F}_{1,35}=1.5, P=\right.$ $0.24)$. Heat load index did not differ among sites for the 3 subspecies $\left(\mathrm{F}_{2,35}=1.2, P=0.32\right)$.

The recovery of canopy cover of mountain big sagebrush fit a $\log$-linear regression model $\left(r^{2}=0.76\right)$ better than a linear model $\left(r^{2}=0.58\right)$. On average, stands of mountain big sagebrush are expected to be $100 \%$ recovered after 32 years (Fig. 2A). A linear model provided the best fit for recovery of Wyoming big sagebrush (Fig. 2B), explaining $52 \%$ of the variation. The actual shape of the full recovery trajectory is not known because recovery was never greater than $5 \%$ in sampled stands. Nevertheless, this model suggests that mean time for full canopy cover recovery is greater than 30 years, and probably much more because 4 of 6 sample plots had no sagebrush cover after as many as 17 years. Recovery of basin big sagebrush could not be modeled with only 4 samples. The mean canopy cover recovery rate $\left(\%\right.$ change $\cdot$ time $^{-1}$ since fire $)$
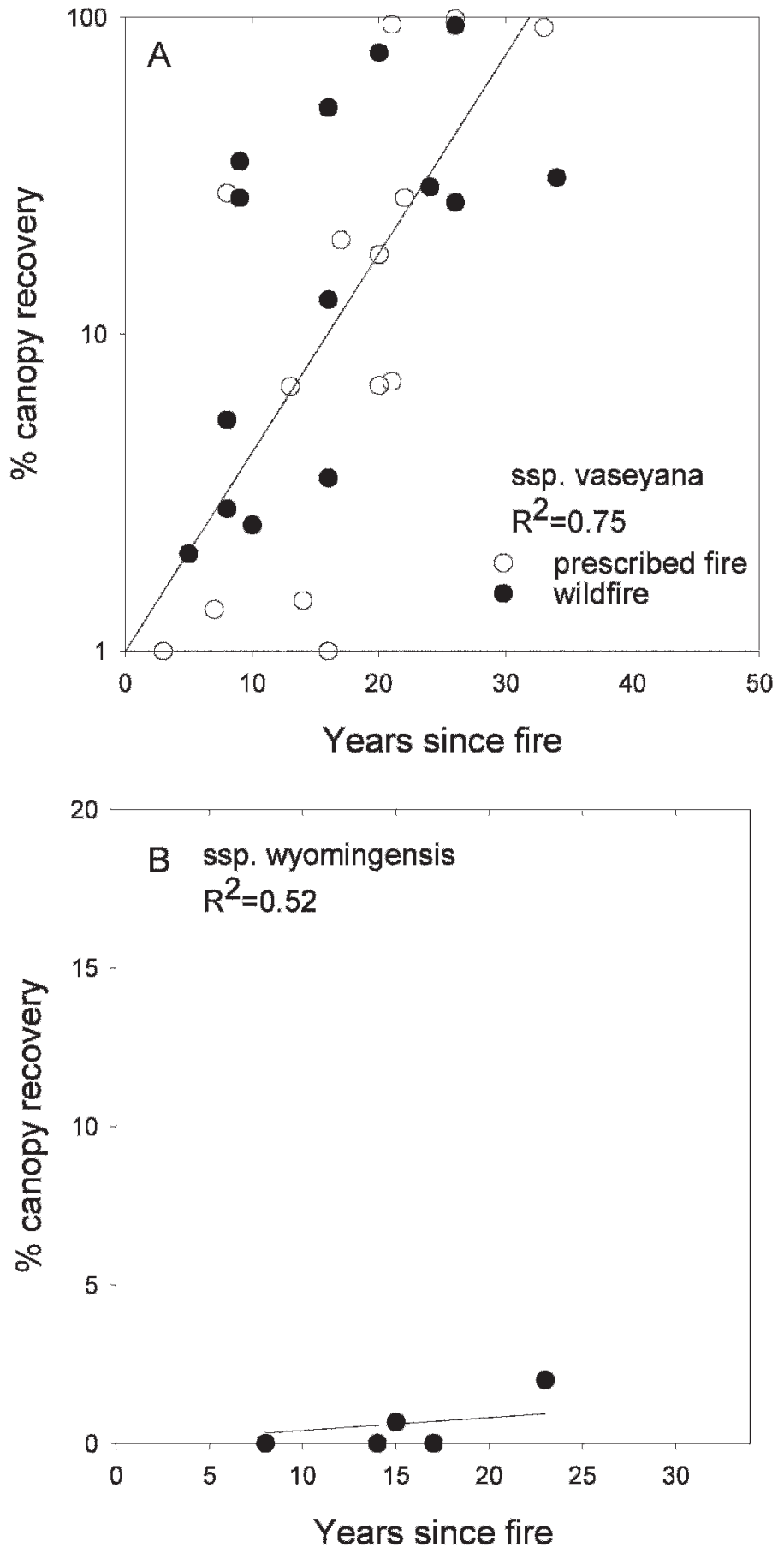

Figure 2. (A) Log-linear relationship between recovery of canopy cover of Artemisia tridentata ssp. vaseyana and time since fire for 28 prescribed fires and wildfires and (B) linear relationship between ssp. wyomingensis recovery and time since fire. Regression lines were constrained to pass through the origin.

for mountain big sagebrush was $1.6 \pm 0.3 \%$ per year, more than 10 times as great as for Wyoming big sagebrush $(<0.1 \%$. year $\left.^{-1} \pm 0.4\right)\left(F_{1,34}=29.5, P<0.001\right)$. Mean recovery rate for basin big sagebrush was $3.0 \pm 1.3 \% \cdot$ year $^{-1}$, greater than the other 2 subspecies $\left(\mathrm{F}_{1,34}=7.3, P=0.011\right)$. Recovery of mountain big sagebrush canopy cover did not differ between wildfire and prescribed fire $\left(\mathrm{F}_{1,25}=2.2, P=0.15\right)$. We were unable to detect a difference among subspecies in the recovery 


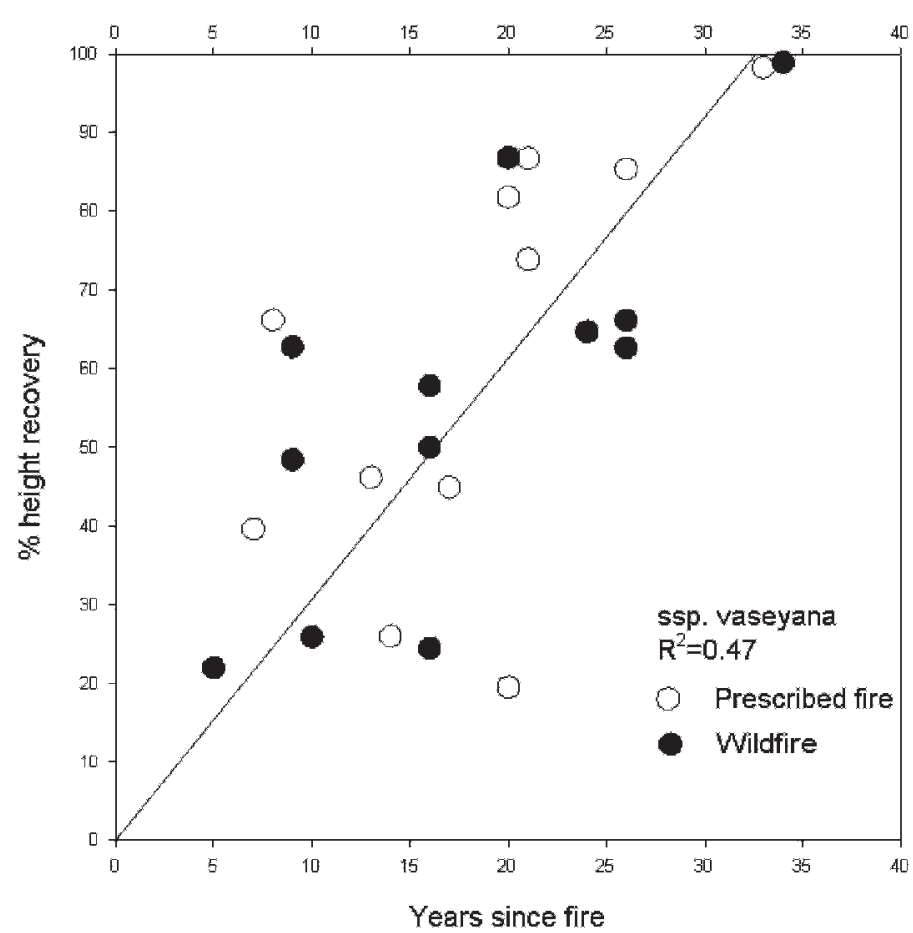

Figure 3. Relationship between recovery of canopy height of Artemisia tridentata ssp. vaseyana and time since fire for 23 prescribed fires and wildfires. Regression model was constrained to pass through the origin.

of canopy height of the dominant cohort $\left(\mathrm{F}_{2,27}=0.85, P=\right.$ $0.44)$. Time to $100 \%$ recovery is projected to be approximately 33 years for mountain big sagebrush (Fig. 3). There was no difference in height recovery between prescribed fires and wildfires in stands of mountain big sagebrush after accounting for age differences $\left(\mathrm{F}_{1,20}=0.1, P=0.72\right)$.

A regression model with heat load, increasing sand content of the soil, and mean annual site precipitation explained 51\% of the variations in rate of sagebrush canopy cover recovery across all subspecies. However, this relationship was driven by differences among subspecies; Wyoming big sagebrush had low recovery rates and occurred in more arid environments whereas basin big sagebrush, with high recovery rates, was found on sandy soils. Heat load, soil texture, and precipitation were not related to sagebrush canopy cover recovery after taking subspecies into account $(P>0.34)$. There was no relationship between canopy cover recovery rate and these 3 abiotic variables when mountain big sagebrush was considered alone $(P>0.54)$.

\section{Three-tip Sagebrush Recovery}

We found no evidence that three-tip sagebrush usually increased following fire. It was present at 9 sites, 6 dominated by mountain, 2 by Wyoming, and 1 by basin big sagebrush. Mean canopy cover of three-tip sagebrush was $6 \pm 3 \%$ in burned plots and $3 \pm 1 \%$ in unburned plots $(t=0.93, P=0.37)$. Three-tip sagebrush density increased greatly at 1 site but declined at 5 sites following fire. As a result, mean density did not differ between burned plots $\left(0.8 \pm 0.4\right.$ plants $\left.\cdot \mathrm{m}^{2}\right)$ and unburned plots $\left(0.7 \pm 0.3\right.$ plants $\left.\cdot \mathrm{m}^{2} ; t=0.20, P=0.85\right)$. Mean height of the dominant size class of three-tip sagebrush plants did not differ between burned plots $(46 \pm 14 \mathrm{~cm})$ and

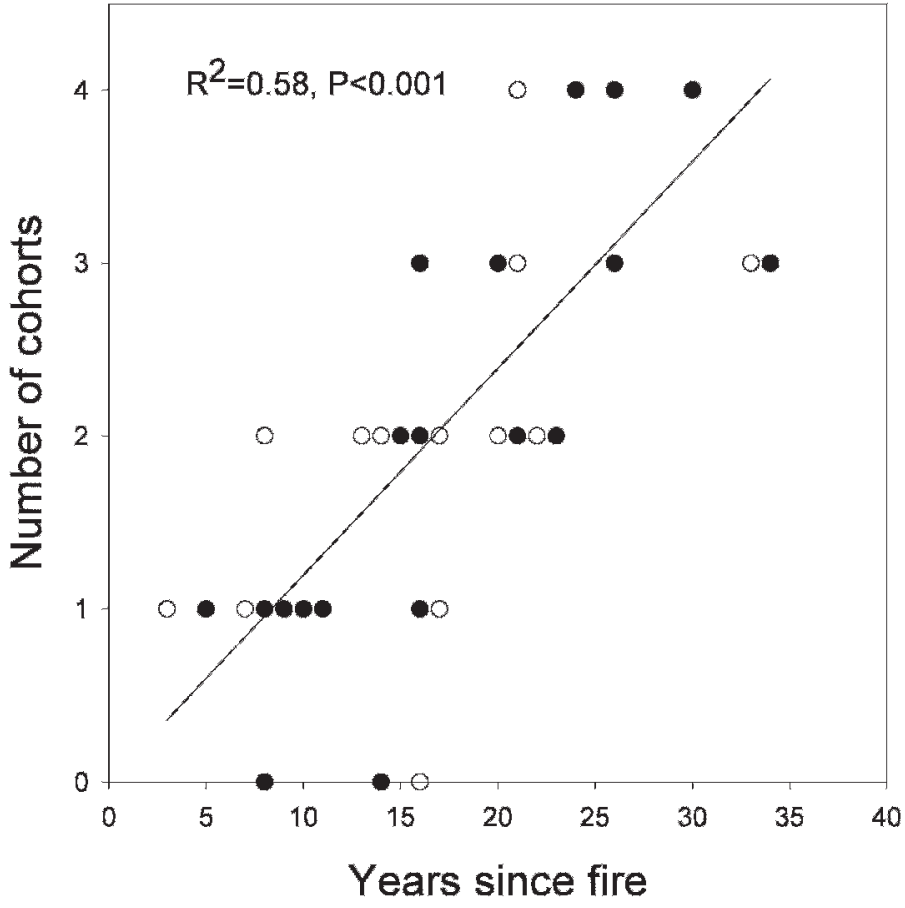

Figure 4. Relationship between the number of sagebrush cohorts (evenage \pm 2 yrs groups) and time since fire for 38 prescribed fires $(\bigcirc)$ and wildfires (๑). Regression model was constrained to pass through the origin.

unburned plots $(43 \pm 8 ; t=0.45, P=0.67)$. Of the 55 threetip sagebrush plants in burned macroplots for which we believe an accurate age was determined, only $6(12 \%)$ survived fire, and the majority of plants in burned macroplots were the age of the burn $( \pm 1 \mathrm{yr})$ in 4 of 9 stands. Mean survival of three-tip sagebrush was $15 \pm 3 \%$ in the Winslow Fire.

\section{Sagebrush Recruitment}

Minimum age of big sagebrush stands (age of oldest plant measured) represented by unburned macroplots ranged from 27 to 66 years. The number of cohorts present in these latesuccessional stands ranged from 1 to 8 with a mean of 5 . The number of big sagebrush cohorts in burned macroplots was strongly associated with time since fire $\left(N=38, R^{2}=0.58, P\right.$ $<0.001$; Fig. 4). When the regression line was constrained to go through the origin, the best-fit linear model had a slope of 0.12 , indicating 1 cohort every 8 years following the fire. After correcting for time since fire, there was no difference in number of cohorts $\left(\mathrm{F}_{2,34}=0.5, P=0.63\right)$ among subspecies of big sagebrush in unburned or burned plots $\left(\mathrm{F}_{2,34}=1.8, P=0.19\right.$. There was no difference between prescribed fire and wildfire macroplots in the number of big sagebrush cohorts $\left(\mathrm{F}_{1,35}=\right.$ $0.2, P=0.68)$ after correcting for time since fire. Annual recruitment was often much higher immediately following fire compared to subsequent years for three-tip and mountain big sagebrush but not for basin or Wyoming big sagebrush (Fig. 5), although sample sizes for the latter 2 taxa were smaller. The number of cohorts was positively associated with mean annual precipitation in burned plots $(N=38, P=0.057)$ but not unburned plots $(N=38, P=0.98)$ after correcting for age. Recruitment of big sagebrush was not strongly associated with 


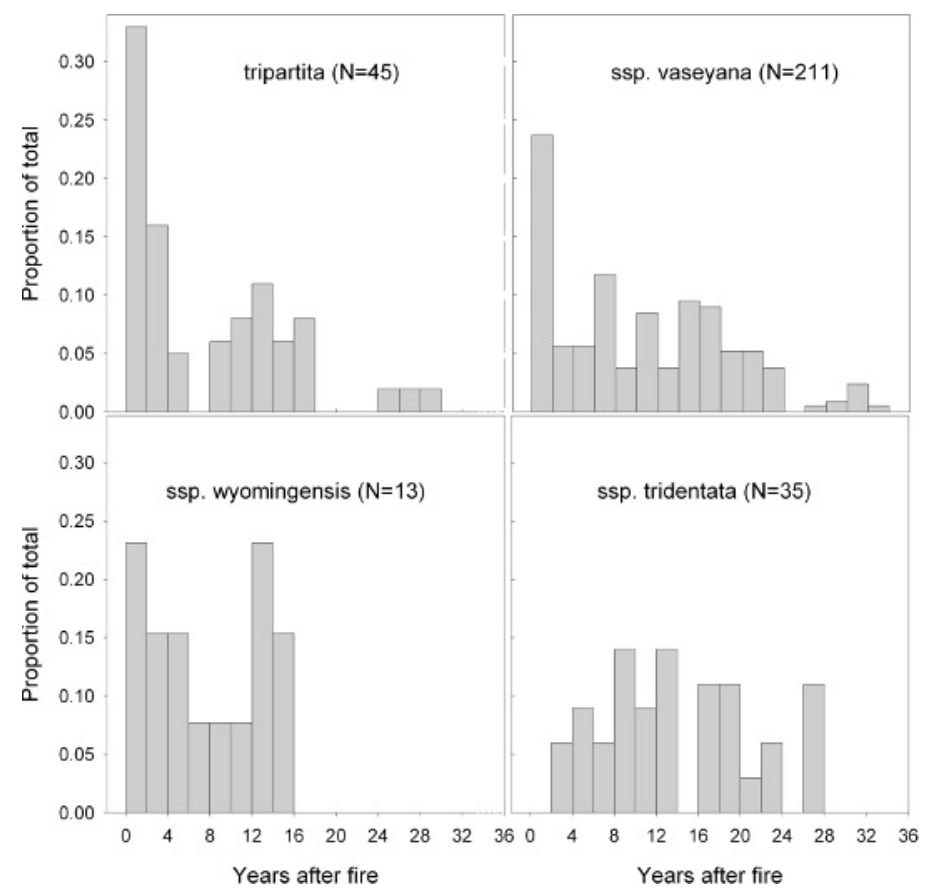

Figure 5. Frequency distribution for proportion of total sagebrush plants recruited in years following fire for 4 taxa; i.e., the left-most bar represents the proportion of the total recruited in the first 2 years following the fire, etc. Only accurate age measurements were used. Plants that survived the fire are not shown.

seasonal precipitation (previous summer, previous fall, winter, spring, summer) across the study area in either burned or unburned plots $\left(R^{2}<0.06, P>0.16\right)$.

\section{DISCUSSION}

\section{Big Sagebrush Post-Fire Recovery}

We observed near complete mortality of big sagebrush in recently burned stands, and the speed with which it recolonized a burned site depended on subspecies. Mean rate of canopy cover recovery was highest for basin and lowest for Wyoming big sagebrush. A log-linear model based on 28 sample pairs predicts that canopy cover of mountain big sagebrush will be fully recovered after 32 years on average (Fig. 2). Our model for Wyoming big sagebrush recovery was based on only 6 sample pairs; nonetheless, it is clear that canopy cover of this subspecies recovers much more slowly because we observed less than $2 \%$ recovery after as many as 23 years in these 6 stands. Full canopy cover recovery of basin big sagebrush was reached within 26 years after fire in 2 of 4 sites studied. Recovery of sagebrush canopy height was similar for the 3 subspecies, and a linear model for mountain big sagebrush suggests that full recovery will be achieved on average after 33 years (Fig. 3).

Variation in the rate of big sagebrush canopy cover recovery among subspecies could be due to differences in recruitment and/or growth. Unfortunately, there is little information on the ability of different subspecies of big sagebrush to recruit in the field. In our study, recruitment of mountain big sagebrush frequently occurred directly following fire, but this postfire recruitment pulse was not observed for the other 2 subspecies
(Fig. 5). Stands dominated by mountain big sagebrush are relatively mesic, whereas Wyoming big sagebrush occupies the driest sites with the most poorly developed soil (Morris et al. 1976; Barker and McKell 1983). Immediate regeneration is expected to be more likely at sites where adequate moisture is more reliable. Prompt recruitment of mountain compared to Wyoming big sagebrush might help explain the relatively fast postfire recovery of mountain big sagebrush canopy cover we observed. The quick recovery of basin big sagebrush canopy cover is more likely due to fast growth. In a controlled greenhouse study, seedling growth rate was lowest for Wyoming and highest for basin big sagebrush (Booth et al. 1990), and this same pattern held for juvenile plants in a common garden (McArthur and Welch 1982).

Recovery of mountain big sagebrush canopy cover was logarithmic, suggesting that recovery rate increased with time. This accelerating recovery was most likely due to increasing biomass accumulation as plants matured. However, there might also have been a positive feedback effect arising from local seed rain once the initial cohort became reproductively mature. Further research is needed to determine the relative contribution of recruitment and growth to canopy recovery.

We were unable to identify any biotic or abiotic factors associated with speed of canopy cover recovery within subspecies. Differences in soil texture and annual precipitation were associated with subspecies identity, which were, in turn, associated with canopy cover recovery rate. However, we hypothesized that among mountain big sagebrush stands on cool slopes or in areas of higher precipitation, canopy cover would recover faster (Johnson and Payne 1968) and that stands on fine-textured soils would recover more slowly (Gruell 1980). However, there was no association between the rate of mountain big sagebrush canopy recovery and mean annual precipitation, heat load, or soil texture, and a model with all 3 abiotic variables explained less than $1 \%$ of the variation in recovery rate.

It is generally believed that proximity to a seed source promotes faster recovery (Blaisdell 1953; Gruell 1980) because the seed bank of big sagebrush is small or non-existent (Akinsoji 1988; Young and Evans 1989). In our study, prescribed burns, for which there were often some surviving plants to act as a seed source, did not recover faster than the more severely burned wildfire sites (most of which had no survivors), a result consistent with results of Wambolt and Payne (1986) who found no re-establishment of Wyoming big sagebrush 6 years after a prescribed fire in spite of the close proximity of a seed source.

Other studies have reported recovery times similar to ours. After 15 years, postburn stands of mountain big sagebrush in southeast Idaho were only approximately $25 \%$ recovered (Pechanec et al. 1954); however, after 30 years they had returned to preburn canopy cover (Harniss and Murray 1973). In another study Humphrey (1984) found that a stand of mountain big sagebrush in southeast Idaho recovered after 20 years. Wambolt et al. (2001) observed a mean of $15 \%$ recovery in 7 of 8 mountain big sagebrush stands $7-16$ years following prescribed fire, consistent with our finding of slow initial recovery rate. However, recovery of mountain big sagebrush canopy cover can be slower. Average recovery following wildfire in south-central Montana was little more 
than $1 \%$ after $11-17$ years (Hoffman 1996). Wyoming big sagebrush usually requires longer recovery time than mountain big sagebrush in Montana. After 18 years, canopy cover of Wyoming big sagebrush was only $12 \%$ of preburn levels following a prescribed fire (Wambolt and Payne 1986). Eichorn and Watts (1984) report that Wyoming big sagebrush failed to recolonize 14 years after wildfire in central Montana. However, Wambolt et al. (2001) found $72 \%$ recovery after 32 years and $96 \%$ recovery after only 9 years in Wyoming big sagebrush stands; however, they studied cool-season, prescribed fires whereas 5 of our 6 samples were wildfires.

Nearly all unburned big sagebrush stands were uneven-aged, indicating that recruitment was not limited to immediate postfire conditions in any of the subspecies. On average, recruitment occurred every 8 years, and a mean of 5 cohorts were present in late-seral stands. Similar results have been obtained for south-central Montana (Hoffman 1996) and eastern Idaho where mountain big sagebrush stands support plants of many ages with small pulses of recruitment occurring at more-or-less regular intervals (West et al. 1979; Perryman et al. 2001). Our results suggest that postburn recruitment occurs more frequently at sites receiving greater precipitation. Although years of exceptionally high recruitment related to climate can occur (Daubenmire 1975), it appears that most recruitment in the immediate postburn years is not related to abnormally high precipitation years (West et al. 1979). These results indicate that big sagebrush is a true climax species, able to reproduce where it is the dominant plant.

\section{Three-tip Sagebrush Post-fire Recovery}

It is usually assumed that three-tip sagebrush increases following fire because it is capable of resprouting, whereas big sagebrush is killed (Daubenmire 1970; Morris et al. 1976; Beetle and Johnson 1982). However, three-tip sagebrush did not increase in the majority of the burns we studied. Furthermore, many plants in burned macroplots appeared to be the same age or younger than the age of the burn, and only $15 \%$ of three-tip sagebrush plants resprouted after the Winslow fire. These findings suggest that three-tip sagebrush might be more sensitive to fire than previously believed and post-fire recruitment from seed might also be important. Further research on the source of three-tip sagebrush recruitment is needed to determine the relative importance of seedlings and sprouts. On average $50 \%$ of three-tip sagebrush plants in burned macroplots were recruited within the 4 years immediately following the fire (Fig. 5), suggesting that frequent fire would be likely to favor its dominance (Passey and Hugie 1962).

\section{Prescribed Fire vs. Wildfire}

Season of burn is often a significant factor in determining the effects of fire in grasslands and shrublands (Howe 1994). Prescribed fires were conducted during early spring and late fall to minimize the chance of losing control. These are times when many native species are dormant, temperatures are cooler, humidity is higher, and fuels are often moister. Wildfires usually occurred during the summer with high temperatures and low humidity and fuel moisture. Several studies have found that prescribed fires affect plant communities differently than wildfire (Biondini et al. 1989; Howe 1995). Our study could not directly test for differences between prescribed fire and wildfire because we did not have both treatments at the same site. Nonetheless, our study design should have allowed us to detect any large differences between these 2 types of fire. However, we found no statistically significant differences in the rate of big sagebrush height or canopy cover recovery between prescribed fire and wildfire. This is surprising because many of the stands burned by prescribed fire supported residual survivors that could act as a seed source, whereas survivors were rare in the sites burned by wildfire.

\section{MANAGEMENT IMPLICATIONS}

Our results can be used to describe the general presettlement occurrence of mountain big sagebrush on the southwest Montana landscape. Mean presettlement fire interval in these communities was estimated to be between 25 and 40 years based on fire-scarred trees at the sagebrush-forest ecotone (Houston 1973; Arno and Gruell 1983; but see Welch and Criddle 2003). Averaged over long time periods and large landscapes, the majority of mountain big sagebrush stands would have been in early or midseral condition because the estimated mean period to full recovery ( 32 years) is approximately equal to the mean fire interval. More precise estimates of the presettlement sagebrush mosaic composition are not possible because of the climatic variability over large temporal and geographic scales. Furthermore, our projection is based on fire-return interval estimates from our study area, and might not apply to other areas of sagebrush steppe.

The rate of sagebrush canopy cover recovery varied among the 3 subspecies of big sagebrush. Our models indicate that stands of mountain big sagebrush, the most common sagebrush in southwest Montana, will recover from fire after an average of 32 years. Prescribed fire could be used to create and maintain multistructured mosaics of this subspecies. Sage grouse require a mixture of open- and closed-canopy sagebrush habitats (Connelly et al. 2000). Maintaining a mosaic of approximately half late-seral and half early-seral stands would require imposing a fire-return interval of about $50-80$ years on all stands in the landscape.

Prescribed fire is not a desirable management option in stands of the other 2 subspecies of big sagebrush. Although we could not construct a reliable model with our limited data, it is clear that Wyoming big sagebrush takes much longer to recover than mountain big sagebrush in our study area. Prescribed fire could result in the loss of the sagebrush resource for many decades in these stands. Only long fire-return intervals will allow stands dominated by Wyoming big sagebrush to remain on the landscape in our study area. Stands of basin big sagebrush usually recover quickly, perhaps in little more than 20 years. However, prescribed fire in these stands seems undesirable because so many have been lost to agriculture (Lesica and Cooper 1997). Further loss to management activity could adversely affect animals dependent on tall sagebrush cover such as pygmy rabbits (Weiss and Verts 1984; Katzner and Parker 1997). Proper identification of sagebrush subspecies is an important precursor to any management activity (Bunting et al. 1987). 
Managers cannot assume that mountain big sagebrush canopy cover or height will recover faster following prescribed fire compared to wildfire. We were unable to identify any abiotic factors associated with faster recovery of mountain big sagebrush canopy cover across our study area. Soil texture, precipitation, and slope aspect have all been reported to influence sagebrush recovery ( Johnson and Payne 1968; Gruell 1980); however, none of them were associated with the rate of canopy cover recovery in our study. We also failed to find an association between distance to seed source and sagebrush canopy cover recovery rate, although our test was indirect. We found no reason to believe that site factors will consistently be associated with recovery time for mountain big sagebrush.

\section{ACKNOWLEDGMENTS}

Brian Hockett, Joe Casey, Brad Gillespe, Jim Roscoe, and John Thompson of the Bureau of Land Management; Gary Hammond of Montana Fish, Wildlife, \& Parks; and Larry Bradshaw, Harriet McKnight, and Kevin Suzuki of Beaverhead-Deerlodge National Forest helped us locate study sites. Many ranchers allowed us to conduct this research on their land. Bob Keane and Alisa Keyser of the Rocky Mountain Forest and Range Experiment Station provided annual precipitation estimates for our study sites. Matt Kauffman helped create the map. Sara Cavin served admirably as a field assistant in the 2004 field season. Soil analyses were performed by the Soils lab at Montana State University. The manuscript was greatly improved by suggestions from 2 anonymous reviewers.

\section{LITERATURE CITED}

AkinsoJl, A. 1988. Postfire vegetation dynamics in a sagebrush steppe in southeastern Idaho, USA. Vegetatio 78:151-155.

AldRidge, C. L., AND R. M. Brigham. 2002. Sage grouse nesting and brood habitat use in southern Canada. Journal of Wildlife Management 66:433-444.

Anderson, J. E., And R. S. Inouye. 2001. Landscape-scale changes in plant species abundance and biodiversity of a sagebrush steppe over 45 years. Ecological Monographs 71:531-556.

Arno, S. F., and G. E. Gruelt. 1983. Fire history at the forest-grassland ecotone in southwestern Montana. Journal of Range Management 36:332-336.

Balley, R. G. 1995. Descriptions of the ecoregions of the United States. 2nd ed. Miscellaneous Publication 1391. Washington DC: USDA Forest Service. 108 p.

Barker, J. R., AND C. M. McKelt. 1983. Habitat differences between basin and Wyoming big sagebrush in contiguous populations. Journal of Range Management 36:450-454.

Beetle, A. A., and K. L. Johnson. 1982. Sagebrush in Wyoming. Bulletin 779 Laramie, WY: University of Wyoming Agricultural Experiment Station. 68 p.

Biondini, M. E., A. A. Steuter, and C. E. Grygiel. 1989. Seasonal fire effects on the diversity patterns, spatial distribution, and community structure of forbs in the northern mixed prairie. Vegetatio 85:21-31.

BLAISDELL, J. P. 1953. Ecological effects of planned burning of sagebrush-grass range on the upper Snake River Plains. Technical Bulletin 1975. Washington, DC: USDA. 39 p.

Booth, G. D., B. L. WeLCH, AND T. L. C. JACOBSON. 1990. Seedling growth rate of 3 subspecies of big sagebrush. Journal of Range Management 43:432-436.

Bunting, S. C., B. M. Kilgore, and C. L. Bushey. 1987. Guidelines for prescribed burning sagebrush-grass rangelands in the northern Great Basin. General Technical Report INT-231. Ogden, UT: USDA Forest Service. 33 p.

Connelly, J. W., M. A. Schroeder, A. R. Sands, and C. E. Braun. 2000. Guidelines to manage sage grouse populations and habitat. Wildlife Society Bulletin 28:967-985.

Daubenmire, R. 1970. Steppe vegetation of Washington. Technical Bulletin 62. Pullman, WA: Washington Agricultural Experiment Station. $131 \mathrm{p}$.
Daubenmire, R. 1975. Ecology of Artemisia tridentata ssp. tridentata in the state of Washington. Northwest Science 49:24-35.

Day, P. A. 1965. Particle fractionation and particle-size analysis. In: C. A. Black [ED.], [ed.-in-chief]. Methods of soil analysis. Part 1. Madison, WI: American Society of Agronomy. p 545-566.

EICHORN, L. C., AND C. R. WATTS. 1984. Plant succession on burns in the river breaks of central Montana. Proceedings of the Montana Academy of Sciences 43:21-34

Eng, R. L., and P. Schladweller. 1972. Sage grouse winter movements and habitat use in central Montana. Journal of Wildlife Management 36:141-146.

Ferguson, C. W. 1964. Annual rings in big sagebrush. Tucson, AZ: University of Arizona Press. $95 \mathrm{p}$.

GruelL, G. E. 1980. Fire's influence on wildlife habitat on the Bridger-Teton National Forest, Wyoming. Volume II. Changes and causes, management implications. Forest Service Research Paper INT-252. Ogden, UT: USDA. Ogden, UT. 35 p.

Harniss, R. O., and R. B. Murray. 1973. 30 years of vegetal change following burning of sagebrush-grass range. Journal of Range Management 29: 167-168.

Harrington, R. D. 2002. A historical perspective of Montana's sagebrush. Intermountain Journal of Sciences 8:61-66.

Hoffman, T. L. 1996. An ecological investigation of mountain big sagebrush in the Gardiner Basin [thesis]. Bozeman, MT: Montana State University. 75 p.

Houston, D. B. 1973. Wildfires in northern Yellowstone National Park. Ecology 54:1111-1117.

Howe, H. F. 1994. Managing species diversity in tallgrass prairie: assumptions and implications. Conservation Biology 8:691-704.

HowE, H. F. 1995. Succession and fire season in experimental prairie plantings. Ecology 76:1917-1925.

HumphreY, L. D. 1984. Patterns and mechanisms of plant succession after fire on Artemisia-grass sites in southeastern Idaho. Vegetatio 57:91-101.

Johnson, J. R., and G. F. Payne. 1968. Sagebrush reinvasion as affected by some environmental influences. Journal of Range Management 21:209-213.

Katzner, T. E., and K. L. Parker. 1997. Vegetative characteristics and size of home ranges used by pygmy rabbits (Brachylagus idahoensis) during winter. Journal of Mammalogy 78:1063-1072.

KLEBENow, D. A. 1969. Sage grouse nesting and brood habitat in Idaho. Journal of Wildlife Management 33:649-661.

KLEBENOW, D. A. 1973. The habitat requirements of sage grouse and the role of fire in management. Proceedings of the Tall Timbers Fire Ecology Conference 12:305-315

LaYcock, W. A. 1991. Stable states and thresholds of range condition on North American rangelands: a viewpoint. Journal of Range Management 44:427-433.

LesICA, P., AND S. V. Cooper. 1997. Presettlement vegetation of southern Beaverhead County, Montana. Helena, MT: Montana Natural Heritage Program. 35 p.

McArthuR, E. D., AND B. L. Welch. 1982. Growth rate differences among big sagebrush (Artemisia tridentata) accessions and subspecies. Journal of Range Management 35:396-401.

McCunE, B., AND D. KeON. 2002. Equations for potential annual direct incident radiation and heat load. Journal of Vegetation Science 13:603-606.

Morris, M. S., R. G. Kelsey, And D. Griggs. 1976. The geographic and ecological distribution of big sagebrush and other woody Artemisias in Montana. Proceedings of the Montana Academy of Sciences 36:56-79.

Müeller-Dombols, D., AND H. Ellenberg. 1974. Aims and methods of vegetation ecology. New York, NY: John Wiley \& Sons. $547 \mathrm{p}$.

[NOAA] National Oceanic and Atmospheric Association. 1982. Monthly normals of temperature, precipitation, and heating and cooling degree days. Montana, 1951-1980. Ashville, NC: National Climate Center. 25 p.

Nesser, J. A., G. L. Ford, C. L. Maynard, and D. S. Page-Dumroese. 1997. Ecological units of the Northern Region: subsections. General Technical Report INT-GTR369. Ogden, UT: USDA Forest Service Ogden. $88 \mathrm{p}$.

Passey, H. B., and V. K. Hugie. 1962. Sagebrush on relict ranges in the Snake River plains and northern Great Basin. Journal of Range Management 15:273-278.

Pechanec, J. F., G. Stewart, and J. P. Blaisdell. 1954. Sagebrush burning good and bad. Farmers' Bulletin No. 1948. Washington, DC: USDA. 34 p. 
Perryman, B. L., A. M. Maier, A. L. Hild, and R. A. Olson. 2001. Demographic characteristics of 3 Artemisia tridentata Nutt. subspecies. Journal of Range Management 54:166-170.

Pyle, W. H., AND J. A. Crawford. 1996. Availability of foods for sage grouse chicks following prescribed fire in sagebrush-bitterbrush. Journal of Range Management 49:320-324.

Roscoe, J. W. 2002. Sage grouse movements in southwestern Montana. Intermountain Journal of Science 8:94-104.

Thornton, P. E., S. W. Running, and M. A. White. 1997. Generating surfaces of daily meteorological variables over large regions of complex terrain. Journal of Hydrology 190:214-251.

WALLESTAD, R. 1971. Summer movements and habitat use by sage grouse broods in central Montana. Journal of Wildlife Management 35:129-135.

Wallestad, R., and D. Pyrah. 1974. Movement and nesting of sage grouse hens in central Montana. Journal of Wildlife Management 38:630-637.

Wambolt, C. L., and G. F. Payne. 1986. An 18-year comparison of control methods for Wyoming big sagebrush in southwestern Montana. Journal of Range Management 39:314-319.
Wambolt, C. L., K. S. Walhof, and M. R. Frisina. 2001. Recovery of big sagebrush communities after burning in south-western Montana. Journal of Environmental Management 61:243-252.

WeIss, N. T., AND B. J. VerTs. 1984. Habitat and distribution of pygmy rabbits (Sylvilagus idahoensis) in Oregon. Great Basin Naturalist 44:563-571.

Welch, B. L., And C. Criddle. 2003. Countering misinformation concerning big sagebrush. Research Paper RMRS-RP-40. Ogden, UT: US Department of Agriculture, Forest Service, Rocky Mountain Research Station. 28 p.

WEST, N. E. 2000. Synecology and disturbance regimes of sagebrush steppe ecosystems. In: P. G.. Entwistle, [ED.]. Proceedings: Sagebrush Steppe Ecosystems Symposium. Publication No. BLM/ID/PT-001001+1150. Boise, ID: USDI Bureau of Land Management. p 15-26.

West, N. E., K. H. Rea, and R. 0. Harniss. 1979. Plant demographic studies in sagebrush-grass communities of southeastern Idaho. Ecology 60:376-388.

Westoby, M., M. Walker, and I. Noy-Meir. 1989. Opportunistic management for rangelands not at equilibrium. Journal of Range Management 42:266-274.

Young, J. A., and R. A. Evans. 1989. Dispersal and germination of big sagebrush (Artemisia tridentata) seeds. Weed Science 37:201-206. 